\title{
菌破壊液滴下により発生したイヌの初期歯肉炎について
}

第 2 報 特にFusobacterium 菌破壊液の免疫犬を使用した場合

\author{
山岸茂 \\ 新潟大学歯学部歯科保存学第 2 教室 \\ (指導 : 原 耕二 教授) \\ (昭和 56 年 9 月 20 日受付)
}

\section{Initial Gingivitis Induced by Topical Application of Sonicates from Oral Microorganisms in Dog}

\section{The Effect of Fusobacterium Sonicate on Immunized Dog}

\author{
Shigeru YAMAGISHI \\ Department of Periodontology and Endodontics Niigata University School of Dentistry
}

(Director : Prof. Kohji HARA)

The aim of present study was to examine the effect of immunization on the initial inflammatory changes in the marginal gingiva.

Two dogs were used. After Fusobacterium sonicate was topically applied to two jaw quadrants of the dogs with clinically healthy gingivae for 8 hours, gingival strips were obtained. Furthermore, similar topical application was carried out in the remaining quadrants of the dogs which had been immunized by Fusobacterium sonicate and the gingival strips were also taken. The gingival strips were fixed in $10 \%$ formalin and embedded in paraffin. The serial buccolingual cross sections of $5 \mu \mathrm{m}$ thickness were prepared and stained with hematoxylin and eosin, Masson Goldner and PAS - Alcian blue.

The histologic sections showed that in the immunized dog, after topical application of Fusobacterium sonicate the numbers of polymorphonuclear leucocytes in the marginal gingiva tended to increase as compared with those before immunization.

This fact may reflect the leucocyte chemotaxis via complement activation in a classical pathway.

\section{緒論}

歯周病発生の原因としては, 一般にプラク中の細菌が 主役を演ずると考えられ ${ }^{1 \sim 5)}$, その発生機構として細菌 の産生酵素や細菌の代謝産物または菌体成分などの細胞 毒が因子として考えられる一方, 歯周組織中の抗体や補 体または末梢リンパ球などの関与する免疫学的役割につ いても解明されてきた ${ }^{6 \sim 13)}$ 。

本論文の要旨は, 昭和 56 年 5 月第 24 回春季日本歯周病学会 総会において発表した。
本教室の吉江は, Actinomyces viscosus,Fusobacterium nucleatum の超音波破壊液を用いた in vitro 実験にお いて, マウス脾細胞は抗体産生を増強すること ${ }^{14)}$, さら にその作用機作を実験的に明らかにした ${ }^{15)}$ 。

すでに著者は, 第 1 報 ${ }^{16)}$ で報告のと抢り，これら菌の 破壊液をイヌの健康歯肉港に 8 時間連続滴下するという in vivo 実験を行い，歯肉上皮ならびに結合組織中に多 形核白血球の浸潤を中心とした初期病変が発生し, しか もその変化は, Fusobacterium で著明であることを明ら かにした。

そこで本研究は, A. viscosus より強い病変をもたら 
表 1 実験の概要
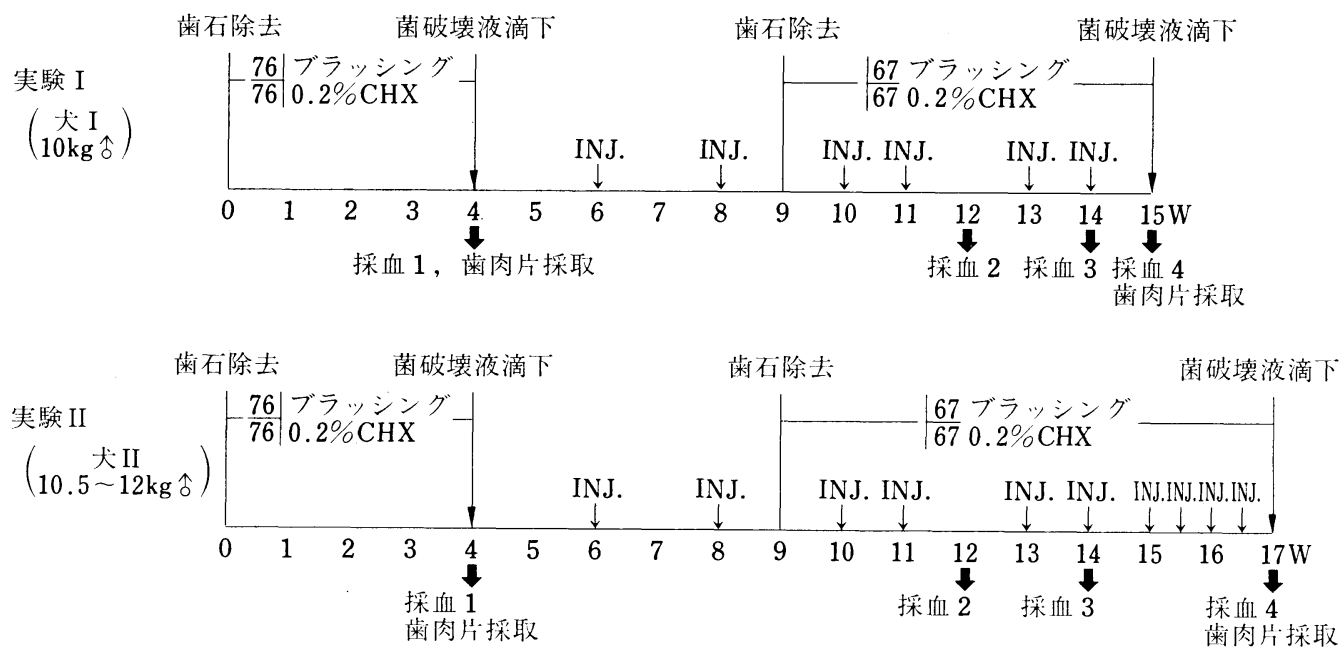

すことがはっきりした F. nucleatum の菌破壊液で予め イヌを免疫しておき，この免疫犬に同じ菌破壊液を健康 歯肉作用させた場合，歯肉の変化はいかなる影響を受 けるかを検討すべき，以下の実験を行った。

\section{研究材料と方法}

\section{実験の概要}

雑種成犬 2 頭（体重 10～12 kg, 年齢不明）を用い，ま ず右側上下䫟小臼歯部: $\frac{76}{76} \mid$ を免疫前の対照側とし，ケ タラール $50(0.3 \mathrm{~m} l / \mathrm{kg})$ の筋肉内注射による全身麻酔 下で歯石除去を行った。その後 4 週間その部の煩側歯肉 に 1 日 1 回徹底したブラッシングと $0.2 \%$ クロールヘキ シジン溶液の噴霧塗布を続けた。健康歯肉の確立後, ケ タラールの筋肉内注射とネンブタール® $(0.5 \mathrm{ml} / \mathrm{kg})$ の 下肢静脈内注射併用による全身麻酔下で，下肢静脈より 約 $10 \mathrm{~m} l$ 採血し，血清中の $F$. nucleatum に対する抗体 価を測定した。その後，イヌを背位に固定したのち， $\frac{76}{76} \mid$ の煩側歯肉辺縁中央の歯肉㵱入口に, 1 歯当り 1 枚静 置した濾紙片（幅 $3 \mathrm{~mm} \times$ 長さ $5 \mathrm{~mm}$ ）を介して，第 1 報 と同様な方法で調整したタンパク 濃 度 $2 \mathrm{mg} / \mathrm{m} l$ の $F$. nucleatum の菌破壊液を, ファイン・ピペットにて 1 カ 所 1 回 $10 \mu l$ ずっ 10 分間隔で 8 時間連続滴下した。使 用濾紙片は 6 回滴下ごとに新しい濾紙片と交換した。滴 下終了後, 滴下部の各煩側歯肉辺縁中央部から, 幅約 $5 \mathrm{~mm} \times$ 長さは歯肉辺縁から歯肉煩移行部までとした 短冊形の歯肉片を採取した。その後，表 1 に示すごと
く, 犬 I , II とも 6 週から免疫を開始した。犬 I では F. nucleatum の菌破壊液 $1 \mathrm{~m} l$ (タンパク濃度 $5 \mathrm{mg} / \mathrm{ml}$ ) と完全フロインドアジュバント $1 \mathrm{~m} l$ の混合液 計 $2 \mathrm{~m} l$ を 6,8 週にイ又の四肢掌および背部数 カ所に, 1 力 所 $0.05 \sim 0.1 \mathrm{~m} l$ の割合で注射し, 9 週より免疫後の 実験側と定めた左側上下顎小目歯部：| $\frac{67}{67}$ の歯石除去お よびブラッシングと $0.2 \%$ クロールヘキシジン溶液の噴 霧塗布を開始した。さらに 10,11 週にタンパク濃 度 $0.05 \mathrm{mg} / \mathrm{ml}, 13,14$ 週に $0.5 \mathrm{mg} / \mathrm{m} l$ の $F$. nucleatum の 菌破壊液を毎回 $20 \mathrm{~m} l$ 静脈内注射した。12, 14, 15 週に 下肢静脈よりおのおの約 $10 \mathrm{~m} l$ 採血し，F.nucleatum に 対する抗体価を測定した。抗体価の上昇を確認した 15 週に，健康歯肉を確立した $\mid \frac{67}{67}$ 部を使用して，対照側と 同様 F. nucleatum の菌破壞液を，煩側歯肉辺縁中央の 歯肉溝入口においた滤紙片を介して, 10 分間隔で 8 時 間連続滴下した。滴下終了後歯肉片を採取した。

犬IIでは 14 週までは犬 I と同様の操作をおこなった が，F. nucleatum に対する抗体価が上昇しなかったた め, 15 週から 17 週の間に 4 回, 毎回タンパク濃度 $1 \mathrm{mg} / \mathrm{m} l$ の . nucleatum の菌破壊液 $20 \mathrm{~m} l$ を静脈内注 射した。17 週に採血し, 血清中の抗体洒測 定と, 犬 I と同様, 健康歯肉を確立した $\mid \frac{67}{67}$ 部に F. nucleatum の 菌破壊液を 10 分間隔で 8 時間連続滴下し，歯肉片を採 取した。

各時期に採血したイヌの血清中の $F$. nucleatum に対 する抗体価は次の 2 つの方法, 1) 沈降反応 (ゲル 搪 散 法)，2)間接赤血球凝集反応（塩化クロム法）により 測 
表 2 血清中の抗体価

\begin{tabular}{|c|c|c|c|c|}
\hline 血清 & & 宎 & 反 広 & \\
\hline 実験(犬） & 1 & 2 & 3 & 4 \\
\hline I & 0 & 2 & 4 & 4 \\
\hline II & 0 & 0 & 0 & 0 \\
\hline 血清 & \multicolumn{4}{|c|}{ 間接赤血球凝集反応 } \\
\hline 実験(犬） & 1 & 2 & 3 & 4 \\
\hline I & 4 & 512 & 1024 & 2048 \\
\hline II & 16 & 32 & 256 & 512 \\
\hline
\end{tabular}

実娩 I (犬I )

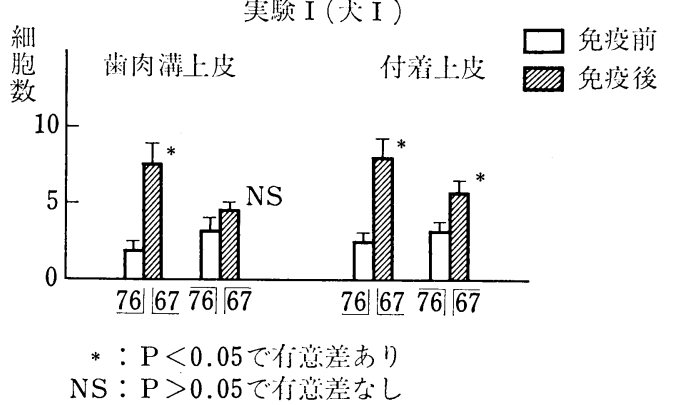

図 1 歯肉上皮の多形核白血球数

表 3 歯肉上皮の多形核白血球数 実験 I (犬 I)

\begin{tabular}{|c|c|c|c|c|}
\hline & 免 疫 前 & 免疫後 & 免 疫 前 & 免 疫 後 \\
\hline \multirow{2}{*}{ 部 } & 76) & 67 & 76 & $\sqrt{67}$ \\
\hline & $\bar{X} \quad$ S. E. & $\overline{\mathrm{X}}$ S.E. & $\bar{X} \quad$ S. E. & $\bar{X} \quad$ S.E \\
\hline 歯肉溝上皮 & $2.0 \pm 0.4$ & $7.6 \pm 1.5$ & $3.2 \pm 0.7$ & $4.4 \pm 0.6$ \\
\hline 付 着 上皮 & $2.5 \pm \underline{0.6}$ & $8.1 \pm 1.3$ & $3.3 \pm 0.5$ & $5.6 \pm 0.8$ \\
\hline
\end{tabular}

* : $\mathrm{P}<0.05$ で有意差あり

NS : P > 0.05で有意差なし
定を行った ${ }^{17)}$ 。

採取した歯肉片の組織標本の作製にいたるまでの操作 は，第 1 報16)の方法に準じて行った。

\section{組織学的検索}

観察部位は, 各被検歯の歯肉上皮で 1)歯肉溝上皮 と 2)付着上皮の 2 力所と, これら上皮值下結合組織の 2 力 所の合計 4 部位とし, 細胞数の測定は接眼レンズにセッ トしたプラニメーター中のグリッド数を上皮で 10 グリ ッド, 上皮直下結合組織では 20 グリッドと定めて 行っ た。な拉, 観察頂目, 細胞の同定, 歯肉微細血管の拡 張, 歯肉上皮細胞間腔の拡大, 歯肉結合組織線維の破壊 の判定は第 1 報16) と同じ基準に従って行った。

\section{結 果}

\section{血清中の F. nucleatum に対する抗体価}

表 2 亿示すとおり実験 I（犬 I） は, 免疫前, 沈降 反 応 0 , 間接赤血球凝集反応 4 であったのが, 免疫後の菌 破壊液滴下時（4回目 の採血時）には，沈降反応 4 , 間
接赤血球凝集 反応 2048 と増加した。一方, 実験 II（犬 II） では，免疫前，沈降反応 0 , 間接赤血球凝集反応 16 で，免疫後の菌破壊液滴下時（4 回目の採血時）には, 沈降反応 0 , 間接赤血球凝集反応 512 と, 実験 I (犬 I ) に比較して抗体価の上昇は少なかった。

\section{組織学的所見}

\section{実験 I (犬 I)}

\section{歯肉上皮の多形核白血球（表 3 , 図 1 )}

1）歯肉溝上皮

76 で免疫前 $2.0 \pm 0.4$ であつたのが, 免疫後 67 で 7.6 \pm 1.5 と免疫前の約 4 倍増加し, 両者の閒で統計学的に 有意差が認められた $(P<0.05) 。 一$ 方, $\overline{76} \mid$ で免疫前 3.2 \pm 0.7 , 免疫後は同7で $4.4 \pm 0.6$ となり, 両者の間に統計 学的に有意差はなかった $(P>0.05)$ 。

\section{2）付着上皮}

付着上皮では， 76 で免疫前 $2.5 \pm 0.6$ であったものが 免疫後 $\mid 67$ で $8.1 \pm 1.3$ と免疫前の約 3 倍増加した。76 では免疫前 $3.3 \pm 0.5$ に対し, 免疫後 $\mid 67$ で $5.6 \pm 0.8$ と 約 2 倍増加し, いずれも統計学的に有意差が認められた 
表 4 歯肉上皮直下結合組織の多形核白血球数 実験 I（犬 I)

\begin{tabular}{|c|c|c|c|c|}
\hline & 免 疫 前 & 免 疫 後 & 免 疫前 & 免疫後 \\
\hline \multirow{2}{*}{ 部 } & $\underline{76}$ & 67 & 76 & 67 \\
\hline & $\bar{X} \quad$ S. E. & $\bar{X} \quad$ S. E. & $\bar{X} \quad$ S.E. & $\bar{X} \quad$ S. E. \\
\hline 蒾肉渄上: 支 & $7.3 \pm 1.2$ & $9.9 \pm 1.5$ & $8.1 \pm 1.0$ & $5.0 \pm 1.1$ \\
\hline 付着上皮 & $5.5 \pm 0.7$ & $9.2 \pm 1.5$ & $10.7 \pm 0.7$ & $5.6 \pm 0.7$ \\
\hline
\end{tabular}

* : $\mathrm{P}<0.05$ で有意差あり

NS：P>0.05で有意差なし

$(\mathrm{P}<0.05)$ 。

歯肉上皮直下結合組織の多形核白血球（表 4, 図 2)

1) 歯肉溝上皮

76 で免疫前 $7.3 \pm 1.2$ ，免疫後 $\mid 67$ で $9.9 \pm 1.5, \overline{76} \mid$ で は，免疫前 $8.1 \pm 1.0$, 免疫後 $\mid \overline{67}$ で $5.0 \pm 1.1$ となり， いずれも統計学的に有意差はなかった（P>0.05）。

2) 付着上皮

76 6 で免疫前 $5.5 \pm 0.7$ に対し, 免疫後 67 で $9.2 \pm 1.5$ と増加し, 一方, $\overline{76} \mid$ では免疫前 $10.7 \pm 0.7$, 免疫後 $\mid \overline{67}$ で $5.6 \pm 0.7$ と減少し, いずれも統計学的に有意差が認 められた $(\mathrm{P}<0.05)$ (図 3 )。

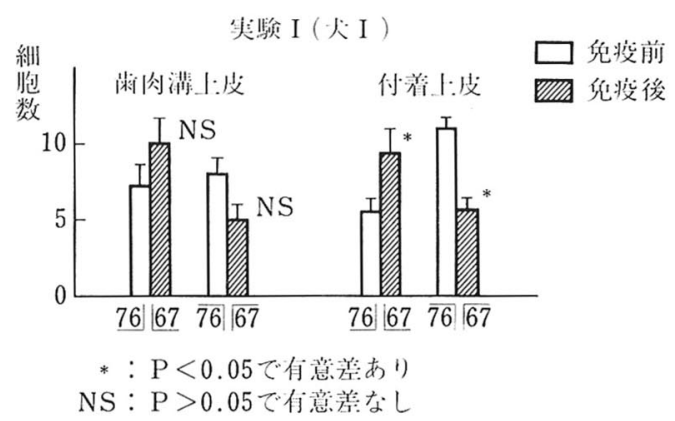

図 2 歯肉上皮直下結合組織の多形核白血球数
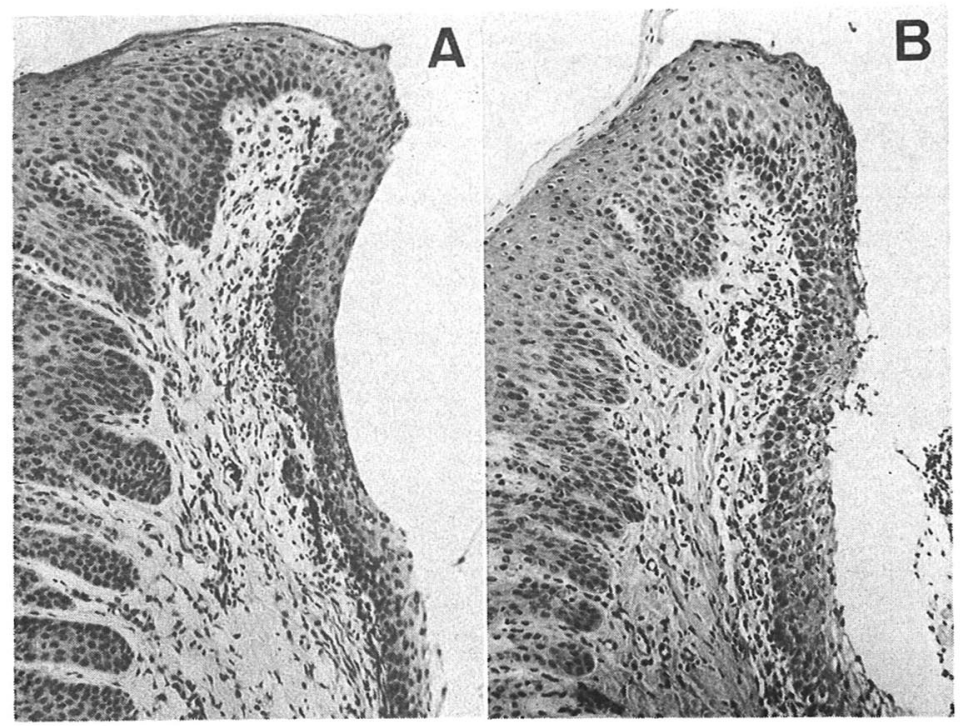

図 3 F. nucleatum の菌破壊液滴下後の組織標本（実験 I）

A. 免疫前：歯肉上皮ならびに歯肉上皮直下結合組織に多形核白血球の浸潤 が認められる，×165，H-E 染色

B. 免疫後：歯肉上皮ならびに歯肉上皮直下結合組織の多形核白血球の浸潤 が免疫前より増加し, かつ微細血管の拡張，上皮細胞間腔の拡大が認め られる, ×165, H-E 染色 
表 5 歯肉上皮の多形核白血球数 実験 II（大 II）

\begin{tabular}{|c|c|c|c|c|}
\hline & 免 疫 前 & 免 疫 後 & 免 疫 前 & 免 疫 後 \\
\hline \multirow{2}{*}{ 部 } & 76 & 67 & 76 & 67 \\
\hline & $\bar{X} \quad$ S. E. & $\bar{X} \quad$ S. E. & $\bar{X} \quad$ S. E. & $\bar{X} \quad$ S. E. \\
\hline 歯肉溝上皮 & $3.5 \pm 0.7$ & $1.5 \pm 0.4$ & $3.9 \pm 1.1$ & $4.7 \pm 0.7$ \\
\hline 付 着 上: 皮 & $1.9 \pm 0.4$ & $3.5 \pm 0.7$ & $6.7 \pm 0.7$ & $6.1 \pm 0.8$ \\
\hline
\end{tabular}

*：P<0.05で有意差あり

NS：P>0.05で有意差なし

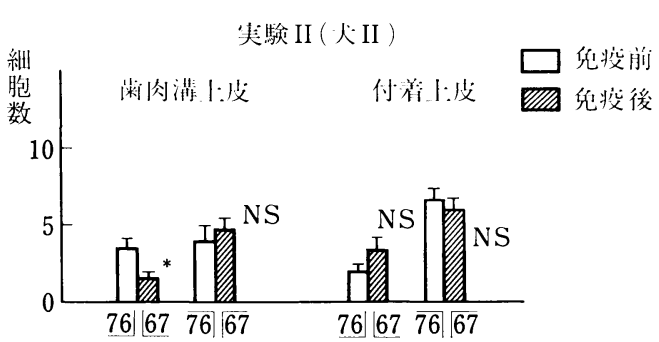

*： $\mathrm{P}<0.05$ で有意差あり

NS：P>0.05で份意差なし

図 4 歯肉上皮の多形核白血球数

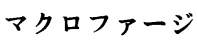

歯肉上皮では, 免疫前, 免疫後ともマクロファージは 認められなかった。歯肉上皮直下結合組織では, 免疫 前, 免疫後とも $0 \sim 4$ の範囲でわずかに認められた。

\section{肥満細胞}

歯肉上皮及び歯肉上皮直下結合組織で，免疫前，免疫 後とも肥満細胞は認められなかった。

\section{形質細胞}

歯肉上皮では免疫前, 免疫後とも形質細胞は認められ なかった。歯肉上皮直下結合組織では, 免疫前, 免疫後 とも 0 〜 2 範囲でわずかに認められた。

\section{リンパ球}

歯肉上皮では, 免疫前, 免疫後ともリンパ球は認めら れなかった。歯肉上皮直下結合組織では, 免疫前, 免疫 後とも $0 \sim 6$ の範囲で認められた。

\section{歯肉結合組織微細血管の拡張}

歯肉微細血管の拡張を歯肉溝上皮及び付着上皮別に観 察したが，免疫前に，歯肉溝上皮直下結合組織に（士） が 1 標本 (3.3\%), 免疫後には, 同じく歯肉溝上皮直下 結合組織に $(+)$ が 1 標本 (3.3\%) 認められたのみで, 他はいずれも微細血管の拡張は認められなかった。

\section{㐘肉上皮細胞間腔の拡大}

歯肉上皮細胞間腔の拡大を歯肉溝上皮及び付着上皮別 に観察したが, 免疫前にはいずれも変化は認められなか った。免疫後, 歯肉溝上皮に（士）が 2 標 本 (6.7\%), 付着上皮では（土）が 3 標本 $(10 \%),(+)$ が 3 標本 (10\%) 認められたが, 他はいずれも上皮細胞間腔の拡 大は認められなかった。

\section{雬肉結合組織線維の破壊}

歯肉結合組織線維の破壊を歯肉溝上皮及び付着上皮別 に観察したが, 免疫前にはいずれも破壊は認められなか った。免疫後, 歯肉溝上皮直下結合組織で（士）が 2 標 本 $(6.7 \%)$ 認められたが，他はいずれも歯肉結合組織線 維の破壊は認められなかった。

\section{実験 II（犬II）}

歯肉上皮の多形核白血球（表 5 , 図4）

1) 歯肉溝上皮

6ㅢ で免疫前 $3.5 \pm 0.7$ であったものが, 免疫後 $\mid 67$ で $1.5 \pm 0.4$ と減少し統計学的に有意差が認められた $(\mathrm{P}<$ $0.05) 。 \overline{76} \mid$ では免疫前 $3.9 \pm 1.1, \sqrt{67}$ で免疫後 $4.7 \pm 0.7$ となり, 両者の間に統計学的に有意差を認めなかった $(\mathrm{P}>0.05)$ 。

2) 付着上皮

76 $\mid$ で免疫前 $1.9 \pm 0.4$, 免疫後 $\mid 67$ で $3.5 \pm 0.7, \overline{76} \mid$ で 免疫前 $6.7 \pm 0.7, \mid \overline{67}$ で免疫後 $6.1 \pm 0.8$ となり, いずれ も免疫前後で統計学的に有意差を認めなかった（P> $0.05)$ 。

歯肉上皮直下結合組織の多形核白血球（表 6, 図 5)

1) 歯肉溝上皮

76 6 で免疫前 $4.2 \pm 0.5$, 免疫後 67 で $2.3 \pm 0.4$ に減少し両 者間で統計学的に有意差が認められた $(\mathrm{P}<0.05)$ 。一方, $\overline{76} \mid$ では免疫前 $5.6 \pm 0.8, \mid \overline{67}$ で免疫後 $5.0 \pm 0.7$ と両者 の間で統計学的に有意差は認められなかった $(\mathrm{P}>0.05)$ 。 
表 6 歯肉上皮直下結合組織の多形核白血球数 実験 II (犬 II)

\begin{tabular}{|c|c|c|c|c|}
\hline & 免 疫 前 & 免疫後 & 免 疫 前 & 免 疫 後 \\
\hline \multirow{2}{*}{ 部 } & $\underline{76}$ & 67 & $\overline{76}$ & $\longdiv { 6 7 }$ \\
\hline & $\overline{\mathrm{X}}$ S.E. & $\overline{\mathrm{X}} \quad$ S.E. & $\bar{X} \quad$ S.E. & $\bar{X} \quad$ S. E. \\
\hline 歯肉溝上皮 & $4.2+0.5$ & $2.3 \pm 0.4$ & $5.6 \pm 0.8$ & $5.0 \pm 0.7$ \\
\hline 付着上皮 & $4.5 \pm 0.5$ & $2.4 \pm 0.3$ & $6.4 \pm 0.8$ & $5.7 \pm 0.7$ \\
\hline
\end{tabular}

* : $\mathrm{P}<0.05$ で有意差あり

$\mathrm{NS} ： \mathrm{P}>0.05$ で有意差なし

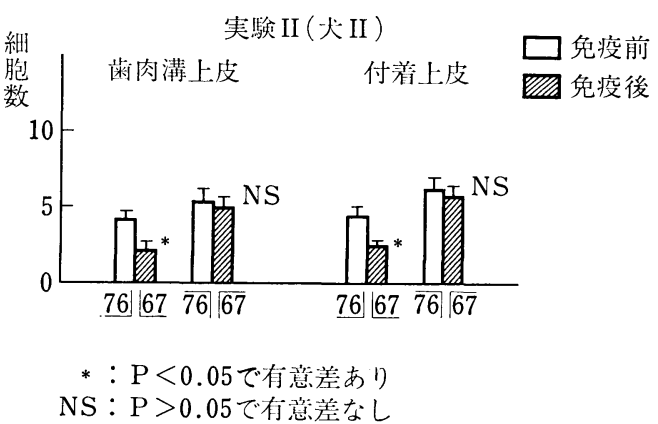

図 5 歯肉上皮直下結合組織の多形核白血球数

\section{2) 付着上皮}

76 6 で免疫前 $4.5 \pm 0.5,67$ で免疫後 $2.4 \pm 0.3$ と減少 し, 歯肉溝上皮同様, 両者の間で統計学的に有意差が認

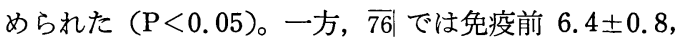
$\mid 67$ で免疫後 $5.7 \pm 0.7$ と免疫前後で統計学的に有意差は 認められなかった $(\mathrm{P}>0.05)$ 。

\section{マクロファージ}

歯肉上皮では，免疫前，免疫後ともマクロファージは 認められなかった。歯肉上皮直下結合組織では, 免疫 前，免疫後とも 0 〜範囲でわずかに認められた。

\section{肥満細胞}

歯肉上皮では，免疫前，免疫後とも肥満細胞は認めら れなかった。歯肉上皮直下結合組織では肥満細胞 1 が免 疫後 3 標本に認められた。

\section{形質細胞}

歯肉上皮では, 免疫前, 免疫後とも形質細胞は認めら れなかった。歯肉上皮直下結合組織では, 免疫前, 免疫 後とも0〜2の範囲でわずかに認められた。

\section{リンパ球}

歯肉上皮では, 免疫前, 免疫後ともリンパ球は認めら れなかった。歯肉上皮直下結合組織では, 免疫前, 免疫
後とも 0 〜の範囲で認められた。

\section{歯肉結合組織微細血管の拡張}

歯肉微細血管の拡張を歯肉溝上皮及び付着上皮別に観 察すると，免疫前には歯肉上皮直下結合組織に（士）が 3 標本 $(10 \%),(+)$ が 6 標本 $(20 \%)$ に認められたが, 他はいずれも歯肉微細血管の拡張は認められなかった。 免疫後, 付着上皮直下結合組織に( $(3.3 \%),(+)$ は歯肉溝上皮直下結合組織に 3 標本 $(10 \%)$, 付着上皮直下結合組織に 1 標本 $(3.3 \%)$ 認めら れたが，他は認められなかった。

\section{歯肉上皮細胞間腔の拡大}

歯肉上皮細胞間腔の抎大を歯肉溝上皮及び付着上皮別 に観察したが，免疫前，免疫後，いずれも拡大は認めら れなかった。

\section{歯肉結合組織線維の破壊}

歯肉結合組織線維の破壊を歯肉溝上皮及び付着上皮別 に観察したが, 免疫前, 免疫後ともいずれにおいても破 壊は認められなかった。

\section{考察}

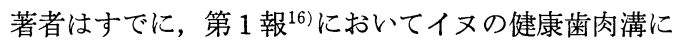
A. viscosus および F. nucleatum の菌破壊液を 8 時間連 続滴下することにより，歯肉上皮ならびに結合組織中に 多形核白血球の浸潤を中心とした初期病変が発生し，し かもその変化は Fusobacterium で著明であることをあき らかにした。

そこで本研究は，A．viscosus より強い病変をもたら すことがはっきりした F. nucleatum の菌破壊液で予め イヌを免疫しておき，この免疫犬に同じ菌破壊液を第 1 報と同様，健康歯肉に作用させた場合，組織学的にどの ような変化が起こるかを観察した。 
免疫操作 ${ }^{18 ~ 22)}$ により, 犬 I では抗体価が免疫前, 沈降 反応 0 , 間接赤血球凝集反応 4 であったものが, 免疫後 に沈降反応 4 , 間接赤血球凝集反応 2048 とともに増加 した。一方, 犬II では免疫前, 沈降反応 0 , 間接赤血球 凝集反応 16 で, 免疫後は沈降反応 0 , 間接赤血球凝集 反応 512 と後者に抒いてのみ抗体価の上昇がややみられ た。

細菌性プラクが作用して歯肉局所に多形核白血球を浸 潤させる因子としては, 1) 菌体成分が直接走化性因子と して作用寸る，2）菌体成分が歯肉中の補体 C 3 に作用 し, 補体を活性化する（副経路を介しての補体の活性 化),3）細菌性抗原と歯肉組織中の抗体が抗原・抗体複 合体を形成し，その抗原・抗体複合体が補体 C 1 亿作用 し, 補体を活性化する（古典経路を介しての補体の活性 化）など 3 つの反応が考えられる。本研究で免疫が成立 した犬 I では F. nucleatum の菌破壊液滴下により免疫 前と比較して歯肉の多形核白血球の浸潤が増加した。一 方, 免疫後抗体価の上昇が低い犬II では歯肉の多形核白 血球浸潤の程度は, 免疫前後で変らなかった。

歯肉炎の初期変化に関して, 免疫反応の役割を考えて みると, 卵白アルブミンで予め免疫したサルに再び卵白 アルブミンを作用させると, 過敏症反応の誘発によって ヒトの歯肉炎に類似した病変が発生すること到や, Kahnberg $ら^{21}$ のヒトのプラク抽出物で免疫したイヌ, ヒト のプラク抽出物で免疫後, 補体を除去したイヌ, 非免疫 犬の 3 群にヒトのプラク抽出物を 10 分閒隔で 6 時間半 作用させた実験では, 多形核白血球の浸潤の増加と歯肉 微細血管の透過性六進が免疫犬においてみられ, 免疫後 補体を除去したイヌではこれらの反応が著しく減少し た。さに horseradish peroxidase (HRP) で免疫した イヌと非免疫のイヌでは HRP の投与後, 免疫犬の歯肉 付着上皮内の多形核白血球数沙免疫大の 6 倍, 単核球 は 2 倍増加したことも報告されており ${ }^{20)}$ ，本研究結果は これら所見とほぼ同じ傾向を示した。そのメカニズムと して過敏症反応而型, 即ち免疫複合体の形成が補体を活 性化し，走化性が生ずると述べている。Genco ら ${ }^{24)}$ は, 歯肉中に免疫グロブリン, 補体が局在することを証 明しており, 歯周病における抗原・抗体複合体の形成, 補体の活性化により血管透過性の克進や走化性が発生す ることで，免疫複合体の役割を説明している。

今回, グラム陰性嫌気性菌である F. nucleatum を使 用したが, Hawley $ら^{25,26)}$ は, 同じくF. nucleatum の 菌破壊液を使用してモルモット補体の消費を検討した結 果, Fusobacterium は副経路を介しての補体の活性化を
促進することを示した。Snyderman ら ${ }^{27,28)}$ は, 多形核 白血球の走化性因子として, 内毒素による補体活性化の 可能性があることを示しておうり, Wennström ら ${ }^{29)}$ は, また多形核白血球の浸潤を起こす因子として, グラム陰 性菌の有する内毒素, リポ多糖類をあげ, これが副経路 を介して補体を活性化すると考えている。さらに Attsröm ら ${ }^{30}$ は, イヌに免疫複合体による補体の活性化を妨 げるカラゲニン (carragheenan)を投与したにもかかわ らず, プラク蓄積後, 歯肉溝内に白血球が浸潤したこと は, 副経路を介しての補体の活性化によるものと考えて いる。

他方, ペルオキシダーゼ (peroxidase) の免疫家鬼に ペルオキシダーゼを歯肉溝に滴下した場合, 結合組織内 に浸透しにくく, かつ歯肉溝上皮には著しく多形核白血 球が浸潤していた。その理由について, McDougal1 ${ }^{31)}$ は, 歯肉溝上皮の細胞間空隙に形成された抗原・抗体複 合体が関与するためと述べている。また Rylander ら ${ }^{22)}$ は, プラク抗原による免疫犬は非免疫犬に比べてプラク の蓄積は同じでも結合組織中の細胞浸潤の広がりと歯肉 沴出液量はむしろ少ないことを観察しておうりこれらの 所見は一種の歯一歯肉付着部での防禦反応の現れと解釈 している。

また, 歯肉滲出液中の免疫グロブリンの濃度は血清中 のそれと似ている ${ }^{32}$ ことから, 免疫犬の茵肉焪出液中の 抗体量泟免疫のときよりも増加し, 歯肉溝中で抗原 . 抗体反応が促進し，抗原を消費することにより歯肉に対 して防禦反応として作用することが考えられる ${ }^{33)}$ 。

以上，多形核白血球の走化性をもたらす因子としては 種々考えられるが, 免疫後, 歯肉組織中の多形核白血球 数が免疫前と比較して増加した本研究結果から, 歯肉に 滴下した F. nucleatum の菌破壊液の抗原と, 免疫操作 により増加した歯肉組織中の抗体とで抗原・抗体複合体 が形成され，補体系を活性化する古典経路が走化性の要 因として成立していることが考えられる。

\section{総括ならびに結論}

本研究は, イヌ 2 頭を用い, まず右側上下頡小曰歯部 を免疫前の対照側とし，歯石除去後 4 週間徽 底したブ ラッシングおよび $0.2 \%$ クロールヘキシジン溶液の噴霧 塗布を行い健康歯肉を確立したのち, 第 1 報と同様に, F. nucleatum の菌破壊液を歯肉溝入口に静置した濾紙 片を介して, 10 分間隔で 8 時間連続滴下した。その後, イヌをF. nucleatum の菌破壊液で免疫し, 抗体価の上 
昇を確認した時点で, 対照側と同様に F. nucleatum の 菌破壊液を滴下した。対照側, 実験側とも滴下終了後, 滴下部の煩側歯肉辺縁中央部から歯肉片を採取し, 歯肉 の変化を病理組織学的に検索した。観察部位は, 歯肉上 皮で1)歯肉溝上皮と2)付着上皮の 2 力所とこれら上皮直 下結合組織 2 力所の合計 4 部位について, 一定面積当り の(1)多形核白血球，(2) マクロファージ，(3) 肥満細胞, (4)形質細胞, (5) リンパ球の各細胞数, (6) 歯肉上皮直下結 合組織にみられる微細血管の拡張, (7) 歯肉上皮細胞間腔 の拡大, (8) 歯肉上皮直下結合組織線維の破壊, の 8 項目 について行った。

その結果，次のような結論が得られた。

1）血清中の F. nucleatum に対する抗体価は, イヌ 2 頭のうち 1 頭 (犬 I ) は, 免疫前, 沈降反応 0 , 間接 赤血球凝集反応 4 であったのが, 免疫後には, 沈降反応 4 , 間接赤血球凝集反応 2048 と増加したが, もう 1 頭 （犬II） は, 免疫前, 沈降反応 0 , 間接赤血球凝集 反応 16 で, 免疫後, 沈降反応 0 , 間接赤血球凝集反応 512 と 抗体価の上昇は少なかった。

2) 免疫後, F. nucleatum の菌破壊液に対する抗体 価が上昇した犬 I で, 同じ菌破壊液を作用させた場合, 歯肉組織の多形核白血球は増加の傾向が認められ, 抗体 価の上昇が少なかった犬IIでは, 免疫前後における歯肉 組織の多形核白血球の浸潤に大きな変化が認められなか った。

3） 2 頭とも, マクロファージ, 肥満細胞, 形質 細 胞, リンパ球の各細胞数, 歯肉微細血管の拡張, 歯肉上 皮細胞間腔の拡大, 歯肉結合組織線維の破壊について は, 免疫前後における変化は認められなかった。

以上, 多形核白血球の走化性をもたらす因子としては 種々考えられるが, 免疫後, 歯肉組織中の多形核白血球 数が免疫前と比較して増加した本研究結果から, 歯肉に 滴下した F. nucleatum の菌破壊液の抗原と, 免疫操 作により増加した歯肉組織中の抗体とで抗原・抗体複合 体が形成され, 補体系を活性化する古典経路が走化性の 要因として成立していることが考えられる。

謝辞 : 稿を終わるにあたり, 終始御懇篤なる御指導と御校閲 を賜りました原 耕二教授に心から感謝申し上げます。また本 研究の遂行に際し, 锠切丁寧な御教示ならびに御助力を賜りま した新潟大学歯学部口腔病理学教室石木哲夫教授に深謝いたし ます。また本研究の実施に当り終始多大な御援助をいただいた 本学歯科保存学第 2 教室の吉江弘正博士ならびに茂手木義男大 学院生に心から感謝するとともに, 同教室員一同に厚く御礼申
し上げます。

なお, 本研究で使用した Fusobacterium は本学口腔細菌学 教室から提供していただきましたことを付記いたします。

本研究の一部は, 昭和 54 年度文部省科学研究費奨励研究 $\mathrm{A}$ 課題番号 477803 の補助で行われたことを付記する。

\section{文献}

1) Löe, H., Theilade, E. and Jensen, S.B. : Experimental gingivitis in man. J. Periodontol., 36 : 177-187, 1965.

2) Theilade, E., Wright, W. H., Jensen, S.B. and Löe, H. : Experimental gingivitis in man II. A longitudinal clinical and bacteriological investigation. J. Periodont. Res., 1 : 1-13, 1966.

3) Löe, H., Theilade, E., Jensen, S.B. and Shiött, C.R. : Experimental gingivitis in man III. The influence of antibiotics on gingival plaque development. J. Periodont. Res., 2 : 282-289, 1967.

4) Socransky, S.S. : Relationship of bacteria to the etiology of periodontal disease. J. Dent. Res., 49 : 203-222, 1970.

5) Kelstrup, J. and Theilade, E. : Microbes and periodontal disease. J. Clin. Periodontol., 1 : 15-35, 1974.

6) Nisengard, R.J. and Beutner, E.H. : Immunologic studies of periodontal disease V. IgG type antibodies and skin test responses to Actinomyces and mixed oral flora. J. Periodontol., 41 : 149-152, 1970.

7) Mackler, B.F., Faner, R.M., Schur, P., Wright, III T. E. and Levy, B. M. : IgG subclasses in human periodontal disease II. Cytophilic and membrane IgG subclass immunoglobulins. J. Periodont. Res., 13 : 433-444, 1978.

8) Norman, M. E., Baehni, P.C., Tsai, C.-C., Stoller, N., McArthur, W.P. and Taichman, N.S. : Studies of host responses during experimental gingivitis in humans II. Changes in acute phase reactants, serum immunoglobulins and complement during the development of gingival inflammation. J. Periodont. Res., 14 : 361369, 1979. 
9) Grass, A., Setterstrom, J. A., D'Alessandro, S. M. and Van Swol, R. L. : Immunoglobulins in periodontal tissues I. Concentrations of immunoglobulins in normal and inflamed gingiva. J. Periodontol., 50 : 581-585, 1979.

10) Ivanyi, L. and Lehner, T. : Stimulation of lymphocyte transformation by bacterial antigens in patients with periodontal disease. Archs. Oral Biol., 15 : 1089-1096, 1970.

11) Smith, F.N., Lang, N.P. and Löe, H.A. : Cell mediated immune responses to plaque antigens during experimental gingivitis in man. J. Periodont. Res., 13 : 232-239, 1978.

12) Church, H. and Dolby, A.E. : The effect of age on the cellular immune response to dento-gingival plaque extract. J. Periodont. Res., 13 : 120-126, 1978.

13) Patters, M. R., Sedransk, N. and Genco, R.J. : The lymphoproliferative response during human experimental gingivitis. J. Periodont. Res., 14 : 269-278, 1979.

14）吉江弘正：口腔常在菌の免疫調節機構 への影響 I. 抗体産生の増強効果について. 日歯周 誌, $21: 134-145,1979$.

15）吉江弘正：口腔常在菌の免疫調節機構 への影響 II. 抗体産生増強の作用機作について. 日 歯 周 誌, $22: 175-186,1980$.

16）山岸 茂: 菌破壊液滴下により発生したイヌの初 期歯肉炎について一主として病理組織学的観察を 中心として一. 日歯周誌, $23: 71-85,1981$.

17）医科学研究所学友会編 : 細菌学実習提要, 丸善株 式会社, 東京, 1976, 239-242 頁, 250-253 頁.

18）宮野哲：Fusobacterium の免疫学的研究 と くに歯周疾患との関連性について，歯科医学, $40: 487-502,1977$.

19) Ahlstedt, S. and Rylander, H. : Immunoradiometric assay for quantification of serum antibodies to dental plaque antigen in immunized dogs. J. Periodont. Res., 10 : 224-229, 1975.

20) Kahnberg, K.-E., Morgan, P. and Lindhe, J. : The cellular response to topically applied horseradish peroxidase in the gingiva of normal and immunized dogs. J. Periodont. Res., 13 : 46-59, 1978.
21) Kahnberg, K.-E., Lindhe, J. and Attström, R. : The effect of decomplementation by carragheenan on experimental initial gingivitis in hyperimmune dogs. J. Periodont. Res., 12 : 479-490, 1977.

22) Rylander, H., Lindhe, J. and Ahlstedt, S. : Experimental gingivitis in immunized dogs. J. Periodont. Res., 11 : 339-348, 1976.

23) Ranney, R. R. and Zander, H.A. : Allergic periodontal disease in sensitized squirrel monkeys. J. Periodontol., $41:$ 12-21, 1970.

24) Genco, R. J., Mashimo, P. A., Krygier, G. and Ellison, S. A. : Antibody-mediated effects on the periodontium. J. Periodontol., $45: 330$ 337, 1974.

25) Hawley, C. E. and Falkler, W.A. : The anticomplementary activity of lipopolysaccharide preparations and sonicates from a strain of fusobacterium nucleatum. J. Periodont. Res., 13 : 24-36, 1978.

26) Hawley, C. E. and Falkler, W.A. : The effect of divalent cation chelators and magnesium on activation of the altenative complement pathway by Fusobacterium polymorphum (nucleatum). J. Periodont. Res., 14 : 390-396, 1979.

27) Snyderman, R., Gewurz, H. and Mergenhagen, S.E. : Interactions of the complement system with endotoxic lipopolysaccharide. J. Exp. Med., 128 : 259-275, 1968.

28) Snyderman, R. : Role for endotoxin and complement in periodontal tissue destruction. J. Dent. Res., 51 : 356-361, 1972.

29) Wennström, J., Heijl, L., Lindhe, J. and Socransky, S. : Migration of gingival leukocytes mediated by plaque bacteria. J. Periodont. Res., 15 : 363-372, 1980.

30) Attström, R. and Larsson, U. : Effect of decomplementation by carragheenan on the emigration of neutrophils and monocytes into dog gingival crevices. J. Periodont. Res., 9 : 165$175,1974$.

31) McDougall, W.A. : The effect of topical antigen on the gingiva of sensitized rabbits. J. Periodont. Res., 9 : 153-164, 1974. 
32) Holmberg, K. and Killander, J. : Quantitative determination of immunoglobuline (IgG, IgA and $\operatorname{IgM}$ ) and identification of IgA-type in the gingival fluid. J. Periodont. Res., $6: 1-8$, 1971.
33) Shillitoe, E. J. and Lehner, T. : Immunoglobulins and complement in crevicular fluid, serum and saliva in man. Archs. Oral Biol., 17 : 241$247,1972$. 